\title{
ANTHRopocene: A Brief Discussion of ANTHRopic INFLuENCE From a PERSPECTIVE OF THE GEOCHEMICAL EvOLUTION OF SURFACE RESERVOIRS AND BIOLOGICAL INSIGHTS
}

\section{NiCOLÁs MisaILIDIS STRÍKIS* AND PEDRO CARLOS STRÍKIS²}

1 Universidade Federal Fluminense, Departamento de Geoquímica, Instituto de Química - Centro, Programa de PósGraduação em Geoquímica, Niterói, Rio de Janeiro, Brazil

2 Universidade de São Paulo, Instituto de Geociências, Programa de Pós-Graduação em Geoquímica e Geotectônica, Butantã, São Paulo, Brazil

*Corresponding author, strikis@gmail.com

Received on 26 August 2018

Received in revised form on 19 September 2018

Accepted on 24 September 2018

Editor: Mauro Geraldes, Universidade do Estado do Rio de Janeiro
Citation:

Stríkis, N.M., Stríkis, P.C., 2018. Anthropocene: a brief discussion of anthropic influence from a perspective of the geochemical evolution of surface reservoirs and biological insights. Journal of Sedimentary Environments, 3 (3): 194-204.

\section{Abstract}

Currently, the extension of human activities allows us to characterize the human being as a geological and biological forcing, capable of generating significant alterations both in the geochemical composition of the main reservoirs of the Earth surface and in biodiversity. Substantial variations of the atmosphere composition as well as of sedimentary constituents deposited in lacustrine environments and in coastal zones allow to easily identifying the anthropic influence on Terrestrial ecosystems. However, the nature of a forcing does not characterize the beginning of a new geological interval, but the extension of its expression on the Earth system. These issues raise a vigorous debate that seeks to understand not only how the human affects the planet, but also how much we can change surface geochemistry and

\section{Introduction}

The Anthropocene represents the most recent temporal clipping of Geological history of Earth, when anthropic activity manifests itself as a geological force capable of promoting substantial changes in the processes that act on the surface of the Planet. The term Anthropocene was formally coined in 2000 by Crutzen and Stoermer in the publication entitled "The Anthropocene" in the Global Change Newsletter (Crutzenand Stoermer, 2000). The expression has its origin in the Greek anthropo-, which means, essentially, "human" and -ceno meaning "new". The suffix ceno is widely used in the nomenclature of the geological epochs contained biological activity. In this context, the search for a marker of Anthropogenic effects in geological materials is an important criterion for determining the Anthropocene as a new geological event on the planet. This paper proposes a brief discussion of the scale about environmental changes due to the anthropic action on the planet surface and its signature in the biogeochemical reservoirs with a view to presenting a suggestion for the beginning of the Anthropocene. Finally, we ponder the fact that we are not the first biological forcing to change the surface of the planet, but without doubt, we are the first forcing that has a moral dimension.

Keywords: Anthropocene. Greenhouse gases effects. Anthropogenic influence.

in the subdivision of the Cenozoic, the current geological Era (Fig. 1).

Sedimentary sequences deposited in the most diverse environments of the planet, both in ice deposits formed in high latitudes areas or in the top of tropical mountains, as well as in shallow to deep oceanic settings or even in lakes distributed by different Earth Climate zones register environmental changes related to anthropic activity. In coastal basins, Anthropogenic sedimentary constituents include increased concentration of aluminum; concrete and plastic characterize a new type of material called "technofossils" (Waters et al., 2016; Zalasiewicz et al., 2016). 
If anthropic activity is equivalent to the geological scale processes that shape the Earth surface, then its consequences are likely to be recorded in geological materials such as the natural climatic and environmental events of the past (Waters et al., 2016). In fact, changes in the composition of the planet atmosphere as well as the contraction of continental-scale biomes resulting from land use and occupation significantly alter biogeochemical cycles on the Earth surface. In this context, anthropic activity has the potential to become a geological-scale event and its consequences can be recorded in the various geological matrices that bear witness to the events of Earth history. Yet there is no consensus regards to the beginning of the Antropoceno. Ruddiman (2013) suggested that the Anthropocene stratigraphic marker may be depicted by the rise of atmospheric methane from 5,000 years ago associated to the spread of rice agriculture in Southern Asian (Ruddiman and Thompson, 2001; Fuller et al., 2011). On the other hand, Steffen et al. (2011) considers that the Industrial Revolution historically marks an important transition of the human enterprise in respect to the consume of natural resource. The burn of fossil fuels and production of fertilizers have boosted the expansion of cropland and grazing areas, changing the land surface at continental scale. In this context the authors points to the year of $1800 \mathrm{EC}$ as the marker of the Anthroponce. Considering the need to establish a common stratigraphic marker, some authors claim for an even earlier beginning for the Anthropocene, then associated to the radiogenic isotope anomaly resulted from the nuclear test during the 1950-1960s (Dean et al., 2014; Waters et al., 2015). If one would equate the Anthropocene to a Period or Geological Age so it must be detectable as such, and therefore its distinction in the geological records must obey the criteria imposed for the other events, otherwise the Anthropocene is an eminently philosophical issue in the context of Earth climate and environmental changes.

\section{Anthropogenic biogeochemical changes of global-scale}

An event of climate and environmental change is likely to become a subdivision in the geological time scale when its expression has global proportions and its record presents clear chronostratigraphic correspondence between different depositional sequences distributed on the surface of the Earth. To do so, we do not necessarily have to go back a long time in Earth history to detect one of these great global events. The Holocene, for example, is one of the last chronological divisions identified on the Geological Time scale and begins at only $11.703 \pm 4$ years before the present, considering the present as the year $2000 \mathrm{CE}$, or Common Era (Fig. 1; Sinha et al., 2013; Rasmussen et al., 2014). The Holocene marks the beginning of the present interglacial period and, unlike the other periods recorded throughout
REVIEW PAPER

the Phanerozoic (geological time span covering the entire macroscopic life span, with about 541 million years of extension), its chronostratigraphic limit is determined from isotopic excursions of oxygen and trace elements measured in Greenland ice cores. These geochemical and isotopic indexes are able to accurately record changes in temperature and variation of ice cover in mid- and high-latitude areas and are, therefore, very useful in determining climatic variations of global expression. The recognition of the Holocene as Time/Series on the chronostratigraphic scale is therefore based on essentially climatic criteria.

Anthropogenic transformations of the earth surface alter the mediations of the biogeochemical cycles with reflections on the nature of the sedimentary constituents deposited on the most diverse environments of the Earth. Geochemical variations of sedimentary deposits include high levels of polyaromatic hydrocarbons, polychlorinated biphenyls, pesticides, among others (Waters et al., 2016). We are today, unequivocally, capable of generating substantial changes in the chemical composition of important compartments of the Earth system, starting with the atmosphere. To the same extent as astronomical forces have dictated the timing of the Quaternary glacial events, affecting $\mathrm{CO}_{2}$ concentrations in the atmosphere, only the burning of fossil fuels and forest biomass over the past 200 years has led to an increase in atmospheric $\mathrm{CO}_{2}$ to levels that do not were observed at least 2.58 million years ago (Fig.2).

To better understand what this means the current climate conditions are then contextualized within a broader time scale. Figure 3 shows the Holocene inserted in a Geological Period known as Quaternary, which began 2.58 million years ago in the Pliocene-Pleistocene transition. The Quaternary marks the beginning of the occurrence of permanent glaciers in the Northern Hemisphere, resulting from a global cooling that is punctuated by a significant reduction of atmospheric $\mathrm{CO}_{2}$ from 340 to about 270 ppm (Figs. 3 and 4) (Bai et al., 2015). The cooling of the Northern Hemisphere and the formation of permanent glaciers allowed the establishment of a cycle of glaciations characterized by the expansion and retraction of polar ice. This cycle, known as the Quaternary Glaciation Cycle, continues to the present (Gibbard et al., 2010). The frequency of these glaciation cycles is controlled by variations of Milankovitch orbital parameters, namely: eccentricity, obliquity and precession. The Quaternary glaciation cycle begins with strong control of the obliquity cycle, generated by the slope variation of the Earth axis and whose periodicity is approximately 41,000 years. However, at about 800 thousand years other orbital cycles begin to control the frequency of the Glaciation cycles. From here, as can be seen in Fig. 3, the glaciation cycles are modulated by a combination of the eccentricity cycle (with average cyclicity close to 100 thousand years) and the precession cycle (with average cyclicity close to 23 thousand years) (Ruddiman, 2008; Cheng et al., 2016). 


\begin{tabular}{|c|c|c|c|c|}
\hline Eon & Era & Period & Epoch & $\begin{array}{l}\text { Age } \\
(\mathrm{Myr})\end{array}$ \\
\hline \multirow{16}{*}{ Phanerozoic } & \multirow{7}{*}{ Cenozoic } & \multirow{2}{*}{ Quaternary } & Holocene & 0.0117 \\
\hline & & & Pleistocene & 2.58 \\
\hline & & \multirow{2}{*}{ Neogene } & Pliocene & 5.33 \\
\hline & & & Miocene & 23.03 \\
\hline & & \multirow{3}{*}{ Paleogene } & Oligocene & 33.9 \\
\hline & & & Eocene & 56 \\
\hline & & & Paleocene & 66 \\
\hline & \multirow{3}{*}{ Mesozoic } & Cretaceous & & 145 \\
\hline & & Jurassic & & 201.3 \\
\hline & & Triassic & & 252.17 \\
\hline & \multirow{6}{*}{ Paleozoic } & Permian & & 298.9 \\
\hline & & Carboniferous & & 358.9 \\
\hline & & Devonian & & 419.2 \\
\hline & & Silurian & & 443.8 \\
\hline & & Ordovician & & 485.4 \\
\hline & & Cambrian & & 541 \\
\hline \multirow{3}{*}{ Proterozoic } & Neoproterozoic & & & 1000 \\
\hline & Mesoproterzoic & & & 1600 \\
\hline & Paleoproterozoic & & & 2500 \\
\hline \multicolumn{4}{|l|}{ Archean } & 4000 \\
\hline Hadean & & & & $\sim 4600$ \\
\hline
\end{tabular}

Fig. 1. Simplified version of the international chronostratigraphic chart.
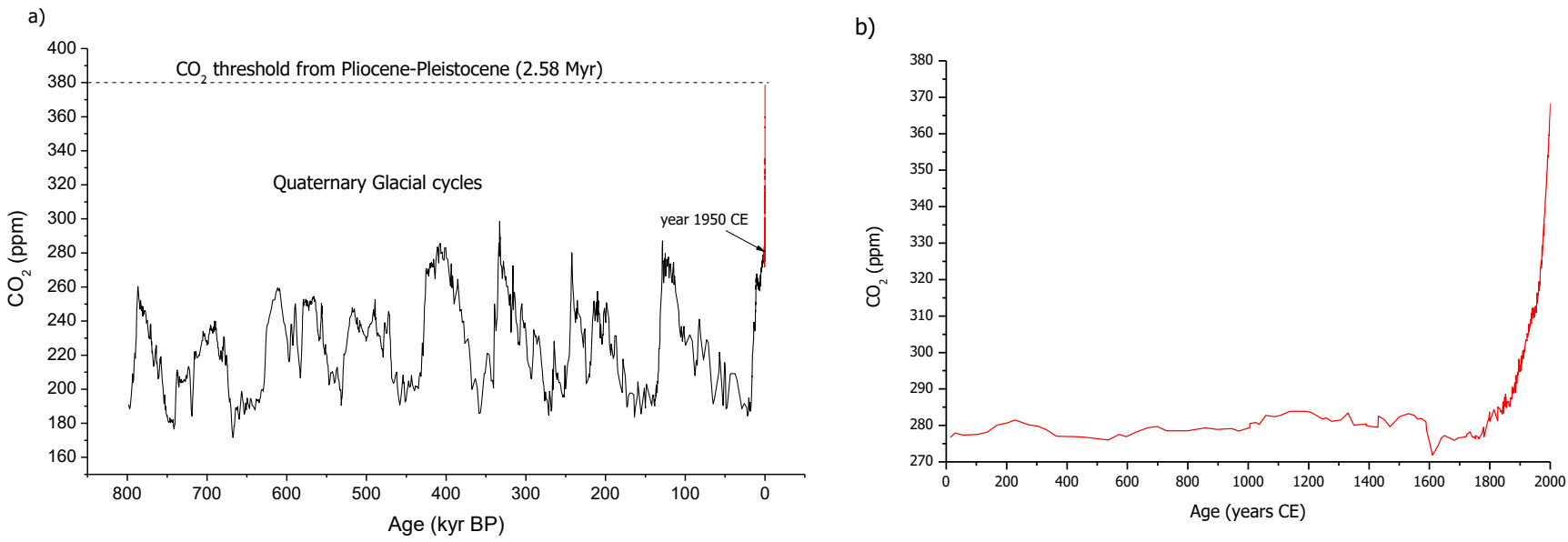

Fig. 2. Global atmospheric $\mathrm{CO}_{2}$ curve measured in Antarctic Ice Dome C: a) series of reconstruction of the last 800 thousand years (Lüthi et al, 2008); b) detailed curve covering the last two thousand years (MacFarling et al., 2006). 
In the more recent history, we notice that fossil fuel burning between the years 1800 and 2015 CE caused a jump of $\mathrm{CO}_{2}$ levels from 280 to $380 \mathrm{ppm}$

The approximately $100 \mathrm{ppm} \mathrm{CO}_{2}$ reached in 200 years is as large as the variations recorded between the Quaternary glacial cycles, which normally have values ranging from 180 and $280 \mathrm{ppm}$ between glacial and interglacial conditions, respectively (Fig. 2 and Fig. 4) (MacFarling et al., 2006; Lüthi et al., 2010). Thus, it has become clear that our capacity of causing changes in the chemical compositions of important geochemical reservoirs, such as the atmospheric $\mathrm{CO}_{2}$, exceeds the natural variability, at least in terms of the glaciological oscillation recorded along the current Geological Period (Fig. 4).
REVIEW PAPER

Other major changes in the chemical composition of the atmosphere reservoir can be observed in methane concentration. Since the spread of irrigated rice agriculture in the southern Asia near 5,000 years ago, the $\mathrm{CH}_{4}$ concentration of the atmosphere has shown a notorious decoupling of the natural variability (Fuller et al., 2011; Ruddiman, 2013).

As can be observed in the Fig. 5, from 5,000 to 1,000 years ago the atmospheric $\mathrm{CH}_{4}$ has increased by about 100 ppb. Such increase represents a decoupling of the natural atmospheric passing recorded over the past glacial cycles of the Quaternary Period. Furthermore, the values are in agreement with estimation of $\mathrm{CH}_{4}$ emission based on rural population growth (Fuller et al., 2011).

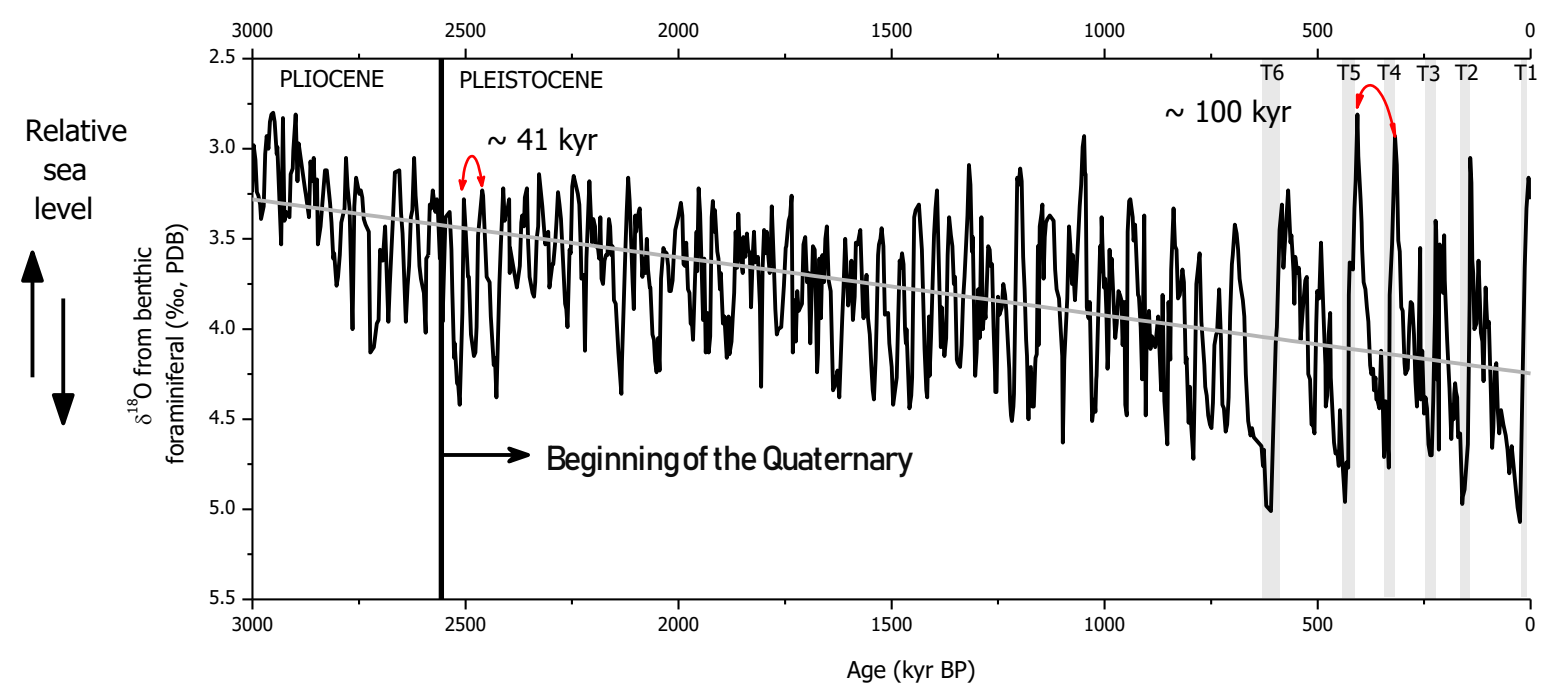

Fig. 3. Quaternary climatic variations based on the $\delta^{18} \mathrm{O}$ isotopic series of Cibicidoides, benthic foraminifera (Raymo et al., 1989). Greater values of $\delta^{18} \mathrm{O}$ are attributed to low sea level periods, associated with the expansion of ice during the glaciation phases. The gray bars T1-T6 mark the completion events of the last glacial phases of the Quaternary.

Important modifications of the biogeochemical cycles are raised by the action of humans, among them, it is important to notice the formation of nitrogenous compounds from mineralized forms of nitrogen through the Haber-Bosh synthesis, which converts $\mathrm{N}_{2}$ to $\mathrm{NH}_{3}$. Currently the amount of nitrogen removed from the atmosphere by human action is about $120 \mathrm{Mt} /$ year, which may exceed the amount generated by the fixation of the atmospheric nitrogen produced by the metabolic activity of bacteria and cyanobacteria, which reaches about 100-300 Mt/year (Galloway et al., 2003). Nitrogen fixation plays a central role in the metabolic activity of animals and plants by transforming the non-reactive nitrogen, as $\mathrm{N}_{2}$, into reactive nitrogen. Reactive Nitrogen encompasses a wide range of organic molecules, including urea, amines, proteins and nucleic acids, as well as inorganic molecules in the form of reduced compounds such as $\mathrm{NH}_{3}$ and $\mathrm{NH}_{4}$ and oxidized forms such as $\mathrm{NOx}_{2} \mathrm{HNO}_{3}, \mathrm{~N}_{2} \mathrm{O}$ and $\mathrm{NO}_{3}$. Since reactive nitrogen is easily mobilized by water and atmosphere, the wide production of these compounds has led to the accumulation of these reactive nitrogen forms in the environment. There is currently more reactive nitrogen material mobilized by human activity in environments than natural processes of denitrification are able to consume.

Between 1800 and $2000 \mathrm{CE}$ the human population grew from one to six billion individuals, while energy use grew by about 40 times and economic production by 50 times (McNeill, 2000). This increase is accompanied by an expansion of human activity on the surface of the Planet. The total amount of land occupied by the human being increased from 10 to something between $25 \%$ and $30 \%$ of the territory. The expression of anthropic activity on the surface of the Earth increased dramatically in the postwar period since 1945. The so-called "Great Acceleration" can be observed in the vertiginous increase of population growth curves, urban growth as well as fertilizer consumption, etc. 


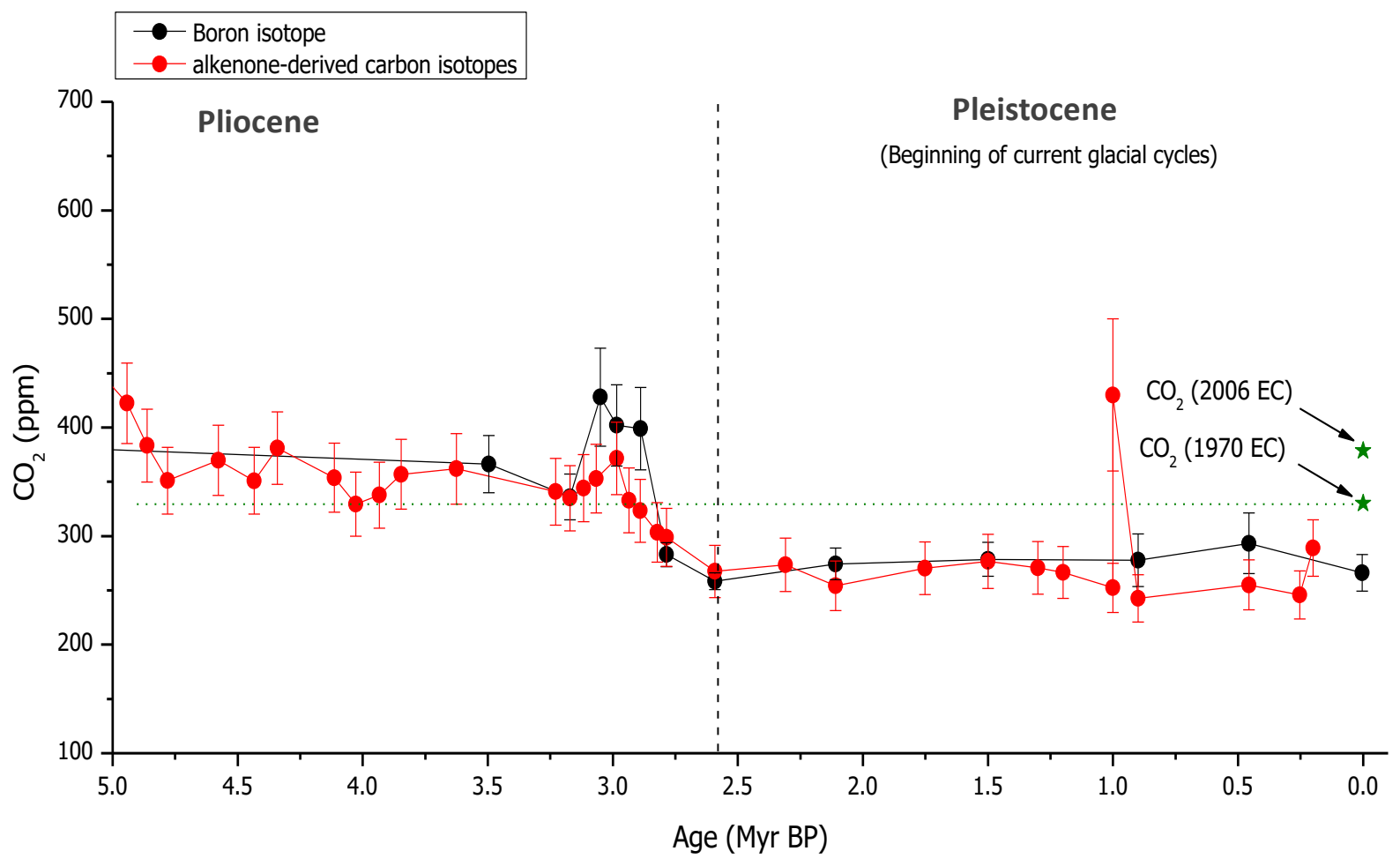

Fig. 4. Reconstitution of atmospheric $\mathrm{CO}_{2}$ based on boron isotopes in foraminifera (black) and alkenone-derived carbon isotopes (red; Beerling and Royer, 2011). Data from Seki et al. (2010) reviewed by Beerling and Royer (2011). Green stars mark atmospheric CO 2 refining values for 1970 and 2006 (MacFarling et al., 2006).

\section{Biodiversity considerations}

Regarding the biodiversity, the extinction rates of eukaryotic species estimated for the present is about 1000 times higher in comparison with natural rates (Pimm et al., 2014; Ceballos et al., 2015). Even ultra-conservative estimates, which seek to minimize extinction rates according to strict criteria for the recognition of an extinct species, indicate that extinction rates have only exceeded natural rates by 114 times in the last 500 years, triggering what was called "the sixth mass extinction" (Ceballos et al., 2015). From the biological point of view the enormous ecological depression imposed by the urban growth and the expansion of the cultivated areas lead to a brutal reduction of the genetic populations variability of diverse ecosystems. Man are responsible for the almost disappearance of extensive biomes, like the Atlantic Forest. This Biome, which until the year $1500 \mathrm{CE}$ stretched over an area of about 1,300,000 km², was reduced to $98,000 \mathrm{~km}^{2}$, i.e. only $8 \%$ of its original coverage (Morellato and Haddad, 2000).

The implications of the severe contraction of these biomes have alarming implications for the biodiversity of the planet as a whole. The decrease in the genetic variability of the populations and consequently of the species variability, especially for species with sexual reproduction, can lead to a process of extinction, which consequently changes the trophic chains of the ecosystems (Lande and Shannon, 1996;
Borrvall et al., 2000; Ives and Carpenter, 2007). This, in turn, decreases the probability of interactions between species causing a cycle of amplification of the extinction process.

Due to the short time of these events, the probability of recovery of these ecosystems is extremely low, dependent on recolonization and the onset of invasive species, which profoundly change the eco-biological functions in the systems in question (Gallardo et al., 2015; Doherty et al., 2016; Mollot et al., 2016; David et al., 2017).

Another important issue to be considered are changes in the adaptive landscapes generated by rapid processes of ecophysiological changes generated by biotic changes of the Carbon, Nitrogen and Phosphorus cycles that can be observed in sediment cores and are important components of the food chain (Canfield et al., 2010; Volanthen et al., 2012; Shibata et al., 2015; Bailey et al., 2015).

The rapid increase of these nutrients has promoted changes in adaptive landscapes, especially to species living in aquatic environments (Ziegler et al., 2016; Crawfurd et al., 2017; Wu et al., 2017). These species become vulnerable to the process of extinction, due to the reduction of population size, but this process also create new adaptive scenarios (new adaptive peaks and valleys; Gavrilets, 2004), since the landscape proposed by Wright (1932) is a function, not only of gene frequencies, but also of ecological processes and gene interactions mediated by environmental stimuli 
(Gavrilets, 2004). New adaptive scenarios can promote the extinction of species, like those that are recorded in the Geologic Time from the end of the Ediacaran to the transition of Cretaceous -Cenozoic period (Halverson et al., 2010; Wang et al., 2013; Zhang et al., 2018). Recently it was
REVIEW PAPER shown that terrestrial insects are prone to extinction due to Global Warming (García-Robledo et al., 2015), so temperature increasing caused by greenhouse gas emissions, especially $\mathrm{CO}_{2}$ can cause large modifications to adaptive landscape scenarios.

\section{Atmospheric $\mathrm{CH}_{4}$ variability of the last} four glacial cycles

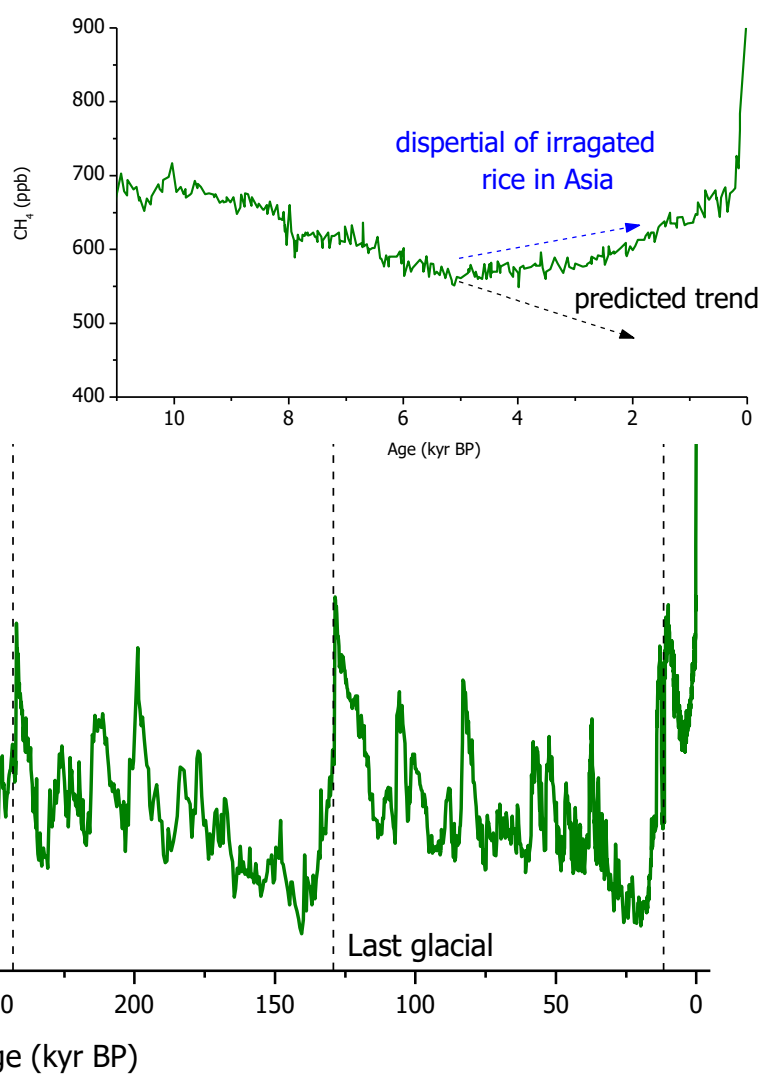

Fig. 5. Atmospheric methane variations recorded during the last four glacial cycles recorded in the Antarctica EPICA Dome C ice-core (Loulergue et al., 2008).

With these processes in mind, we cannot neglect that life on Earth is an extremely complex process dictated by evolutionary micro and macro processes, in addition to stochastic interactions and ecological processes, it is not deterministic, but generates diversity through mutations, recombination and epigenetic processes. At the same time, this diversity is connected to a space and time scale in which interactions must occur to provide this diversity, which also serves to increase the resilience of ecosystems. Sudden changes as the increase in global warming seriously affects the ecosystem as a whole.

4. A proposal for the beginning of the Anthropocene

Despite the evidence of the anthropogenic influence on Earth's climate and environment, there is still no consensus as to when exactly the Anthropocene would begin. These divergences arise precisely when we try to understand which marker best represents the expression of anthropic activity on the environment.
From the geological point of view, it is necessary to think which depositional matrix or sequence best registers these impressions, in order to establish a clear chronostratigraphic marker of global scale that can be correlated between independent record. In this sense, in the geological record what matters is not necessarily when the human being appears as potential agent of changes but when the consequences of its activities reach geological scale proportions. This geological scale in turn does not refer only to a temporal dimension, but to a spatial relationship associated to a stratigraphic marker recognizable worldwide.

A new geological period can be determined both by an event of an abrupt nature, such as the fall of a meteorite about 66 million years ago (end of the Mesozoic Era and early Cenozoic) as by a gradual environment change, as the development of metazoans at the end of the Neoproterozoic (early Phanerozoic Era and the Cambrian Era).

What matters in fact, is how and in which extent this event interferes in the physical and biotic environment. Once this question is determined, a reference frame is 
sought in space and time to officially establish the beginning of a new geological interval.

Ice cores from Greenland and lake sediments from Europe records a wide spread airborne pollution since 150 $\mathrm{BC}$ associated with $\mathrm{Pb}$ mining and smelting process during the Roman Empire (Rosman et al., 1997; Renberg et al., 2002). Although the Anthropogenic variation in atmospheric lead concentration would be detected a millennium before the Industrial Revolution the most significant increase is noticed during the XX century, directly associated to the burning of fossil fuel (Rosman et al., 1997; Renberg et al., 2002; Dean et al., 2014).

Some authors suggest that the radiogenic isotope anomaly resulted from the nuclear test during the 19501960s can ideally fits as a marker for the Anthropoce boundary (Dean et al., 2014; Waters et al., 2015). Among the radioactive isotopes released into the environment during the nuclear tests the Carbon-14 and Plutonium-239 are great candidates as markers for the Anthopocene. Both are rare in nature and present a relative long half-life. For instance, the peak of Carbon-14 at 1963 known as "bomb peak" can be easily recognized in the biological remains as well as in many sedimentary layers containing organic material. With a halflife of 5,730 years, the Carbon-14 spike will be detectable, at least, for about 50,000 years in the future (Dean et al., 2014; Waters et al., 2015). On the other hand, Plutonium 239 has a much bigger half-life (24,110 years) and can last even longer as marker of the Anthropocene boundary.

Back to the ice cores, the dizzying rise in $\mathrm{CO}_{2}$ concentration during what is called the second industrial revolution (second half of the $19^{\text {th }}$ century) is one of the most notorious markers of anthropic activity on a geochemical reservoir. The graph in Fig. 6 shows the rate of atmospheric $\mathrm{CO}_{2}$ increasing in $\mathrm{ppm} /$ year from the peak of the last glaciation, at $\approx 20,000$ years ago (Last Glacial Maximum), to the present. This interval is particularly pertinent because allows us to compare the Anthropogenic forcing with the other forcing relative to the radiative balance, both in the context of the orbital forcing observed in the transitions between a glacial-interglacial cycle, as in natural oscillations associated with volcanic eruptions and other components that can become relevant in the context of the current interglacial.

Another important issue is the fact that this range also fits the resolution of atmospheric $\mathrm{CO}_{2}$ reconstitutions recorded in Antarctic ice cores (MacFarling et al., 2006; Lüthi et al., 2008). In this case, rates are calculated on the basis of average $\mathrm{CO}_{2}$ values at 100 -year intervals. a) last 20 thousand years

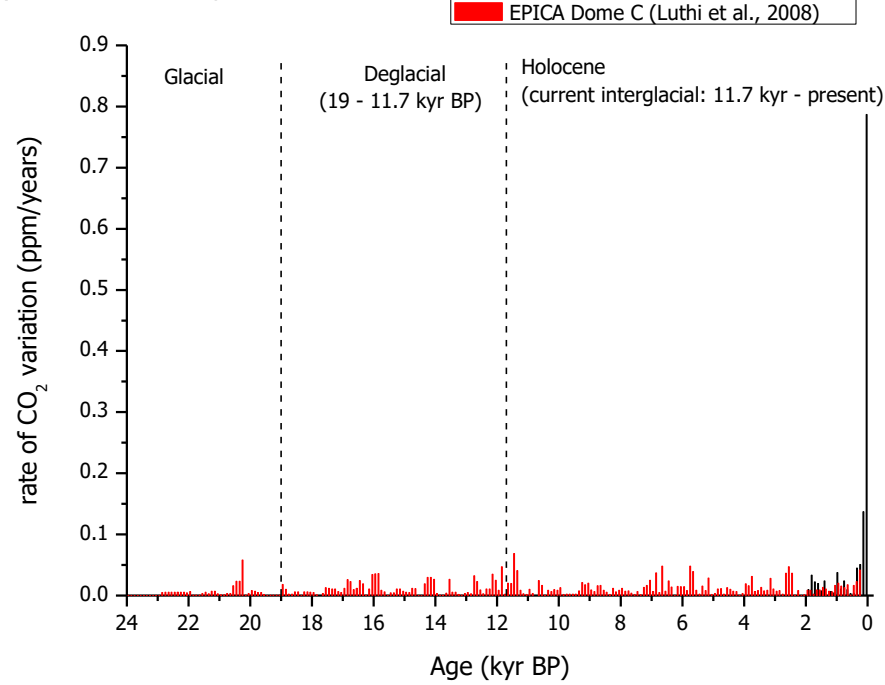

b) last two thousand years

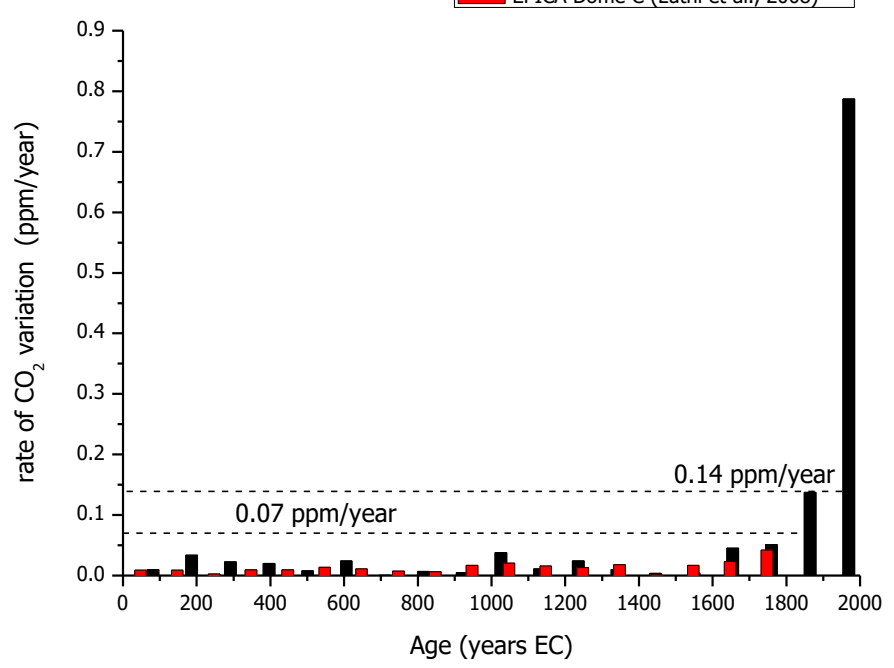

Fig. 6. Absolute change rate of atmospheric $\mathrm{CO}_{2}$ in ppm/year measured in Antarctica Low Dome C (MacFarling et al., 2006) and EPICA Dome C (Lüthi et al., 2008).

As we can see in Fig. 6, the rate of $\mathrm{CO}_{2}$ increase recorded in the mid-nineteenth century is at least twice as high as the variations generated by non-Anthropogenic forcing over the last 20,000 years.

For more anomalous that this variation may be, it cannot necessarily be decisive for the delimitation of a new geological interval. Indeed, it is not necessarily the notoriety of the nature of an event or its frequency, which determines a geological interval. Take as an example the fall of a meteorite. Meteors fall all the time, and even if we had an anomalous increase in their frequency, regardless of the nature of this increase, both frequency and cause would not be determining imperatives for a geological period unless they trigger severe environmental or climatic changes.

Thus, however notable the increase in atmospheric $\mathrm{CO}_{2}$ rates in the early nineteenth century, a directly associated record of climate or environmental change is needed to determine the beginning of the Anthropocene. The same 
hold true for the methane increase noticeable by Ruddiman (2013) related to spread of irrigated rice agriculture across the southern Asia after 5,000 years ago (Ruddiman and Thompson, 2001; Fuller et al., 2011).

Back to twentieth century, in 1970, $\mathrm{CO}_{2}$ levels exceeded the 300 ppm mark, reaching 380 ppm in 2006. As previously stated, those levels have not been recorded since the Pliocene-Pleistocene transition, when temperatures in the high latitudes of the Northern Hemisphere allowed the formation of permanent glaciers (Fig. 4).

Simulations from the Coupled Model Intercomparison Project Phase 5 (CMIP5) presented in the fifth Intergovernmental Panel on Climate Change (IPCC, 2014) assessment report show that since the mid-1970s temperature variations recorded on Earth are not likely to be reproduced in climate models without considering the anthropic forcing in the models (Fig. 7) (Stocker et al., 2013).

In other words, the climate models used in the modeling show that the increase in temperatures since 1970 can only be explained by considering the increase of atmospheric $\mathrm{CO}_{2}$ As can be observed in the Fig. 7, since the 1970s models with only natural forcing (including solar and volcanic forcing) are not able to reproduce the trend recorded in instrumental data (Stocker et al., 2013). On the other hand, once the Anthropogenic $\mathrm{CO}_{2}$ forcing is included, the models finally reproduce the global warming trend recorded in instrumental data (Fig. 7) (Stocker et al., 2013).

\section{Global averages}
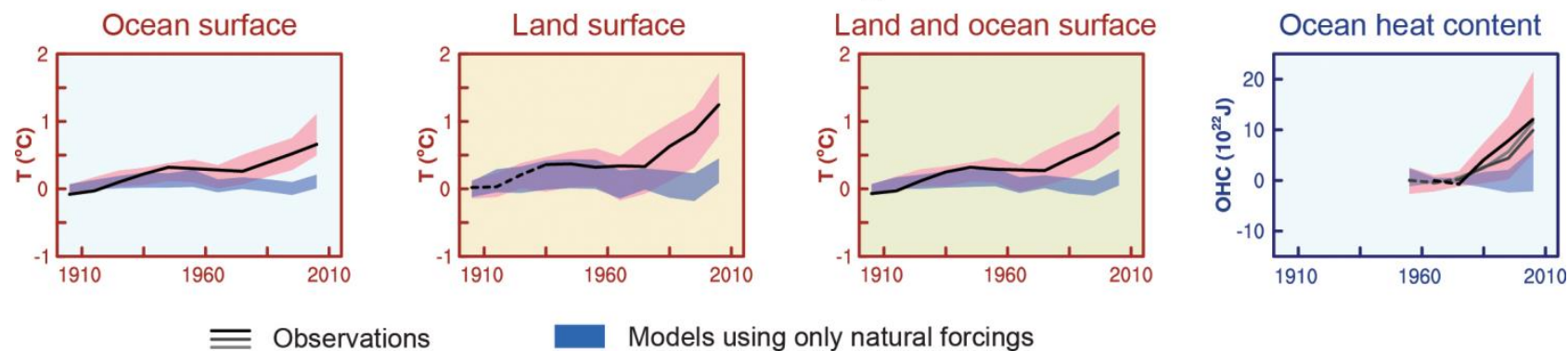

Observations

Models using only natural forcings

Models using both natural and anthropogenic forcings

Fig. 7. Comparison of observed and simulated changes in climate system at global scales. Anomalies are given relative to 1880-1919 for surface temperatures and 1960-1980 for ocean heat content. All time-series are decadal averages, plotted at the center of the decade. For land and ocean surface temperatures panels, solid observation lines indicate where spatial coverage of areas being examined is above $50 \%$ coverage and dashed observation lines where coverage is below $50 \%$. For ocean heat content panel, the solid line is where the coverage of data is good and higher in quality, and the dashed line is where the data coverage is only adequate, and thus, uncertainty is larger. Model results shown are Coupled Model Intercomparison Project Phase 5 (CMIP5) multi-model ensemble ranges, with shaded bands indicating 5 to $95 \%$ confidence intervals. Adopeted from Stocker et al. (2013).

In this sense, we can still define the 70 s as a marker for for the Anthropocene, in the sense of establishing a period where the Anthropogenic forcing becomes a climatic modulator. However, difficulties on recognizing this period in the geological matrixes make it impracticable. The standard stratigraphic practice requires a more globally widespread signature, passive to be recognized in different biogeochemistry matrixes. In this context, the Carbon-14 spike at 1963, the so-called bomb-peak, or even the occurrence of Plutonium-239 in sedimentary sequence at 1950 would be ideally stratigraphic markers for the boundary of the Anthropocene. The contemporaneity of the radioactive isotopes markers as Carbon-14 and Plutonium239 with the remarkable Anthropogenic warming observed during $70 \mathrm{~s}$ points to the nuclear weapons fallout as reasonable markers for the Anthropocene.

The Anthropocene would not be the first time that an organism acts as a natural forcing of geological scale. In fact, the oxidation of the atmosphere by the photosynthetic activity of algae and cyanobacteria during the Proterozoic Eon was determinant for the Earth atmosphere to acquire the composition it has today and to allow the development of more complex organisms. Similarly, the emergence and diversification of vascular plants during the Paleozoic has completely changed the way the rocks are weathered on the Earth surface, shaping the dynamics of the erosion processes and the nature of the sedimentary constituents that accumulate in several basins, above all the oceans. Although we are not the only organisms capable of altering the surface of the planet, we are the first geological forcing thar has a moral dimension. That is, we know what we are doing and we can make choices.

\section{Conclusion}

In this work, we suggest that cause and consequence relations are as close as possible in time and space. In this sense, in an attempt to determine a period for the beginning 
of the Anthropocene we advocate that a landmark should be established during the twentieth century. In this context, the accumulation of radioactive isotopes, such as Carbon-14 and Plutonium-238, peaking at 1963, as the result of the nuclear test, can function as a stratigraphic marker for the Anthropocene.

During the so-called "Great Acceleration" we recorded a significant milestone of the atmospheric $\mathrm{CO}_{2}$ values related to the Anthropogenic forcing, exceeding the amplitude of variation observed during the Quaternary glaciation cycles, reaching values observed only during the Pliocene. Likewise, geochemical anomalies related to the increase of nitrogen, phosphorus, aluminum, lead, organochlorine compounds in addition to the so-called "technofossils" as plastics and concrete incorporate significant signatures of human activity into the geological matrix of the planet. In addition, important changes in biological diversity have been recorded during the last decades due to Global Warming caused by the increasing of atmospheric $\mathrm{CO}_{2}$.

The impacts, however, are not restricted to a set of geochemical anomalies. Severe rises in rates of biodiversity loss already allow us to identify what would be the seventh (considering the End of the Ediacaran-Cambrian extinction) mass extinction event in Earth history. Since 1970 the temperature rise recorded on both the continental and oceanic surfaces is now exclusively related to the greenhouse gas forcing, registering a rise of more than $1{ }^{\circ} \mathrm{C}$ of the global average in less than 50 years. The whole of this evidence, among many others not explored in this article, motivates us to establish the period near $1963 \mathrm{CE}$ as a candidate to shelter the stratotype that would define the Anthropocene as a new Geological interval.

\section{Acknowledgment}

The authors thank to Wania Duleba and Heitor Evangelista da Silva. The research that led to this review was funded by the Fundação de Amparo a Pesquisa do Estado de São Paulo (Fapesp) Project 2017/50085-3.

\section{References}

Bai, Y-J., Chen, L-Q., Ranhotra, R.S., Wang, Q., Wang, Y-F., Li, C-S, 2015. Reconstructing atmospheric $\mathrm{CO}_{2}$ during the PlioPleistocene transition by fossil Typha.Global Change Biology 21, 874-881. https//doi.org/10.1111/gcb.12670.

Bailey, J.K., Schweitzer, J.A., Ubeda, F., Koricheva, J., LeRoy, C.J., Madritch, M.D., Rehill, B.J., Bangert, R.K., Fischer, D.G., Allan, G.J., Whitham, T.G., 2009. From genes to ecosystems: a synthesis of the effects of plant genetic factors across levels of organization. Philosophical Transactions of the Royal Society B. 364, 1607-1616. https//doi.org/ $10.1098 /$ rstb.2008.0336

Beerling, D.J., Royer, D.L., 2011. Convergent Cenozoic $\mathrm{CO}_{2}$ history. Nature Geoscience 4 (7), 418-420. https//doi.org/10.1038/ngeo1186
REVIEW PAPER

Borrvall, C., Enmbeman, B., Jonsson, T., 2000. Ecology Letters 3, 131-136. https//doi.org/10.1046/j.1461-0248.2000.00130.x.

Canfield, D.E., Glazer, A.E., Falkowski, P.G. 2010. The Evolution and Future of Earth's Nitrogen Cycle. Science 330, 192. https//doi.org/10.1126/science.1186120.

Ceballos, G., Ehrlich, P.R., Barnosky, A.D., García, A., Pringle, R.M., Palmer, T.M., 2015. Accelerated modern humaninduced species losses: Entering the sixth mass extinction. Science 1 (5), e1400253. https//doi.org/ $10.1126 /$ sciadv. 1400253

Cheng, H., Edwards, R.L., Shina, A., Spötl, C., Yi, L., Chen, S., Kelly, M., Kathayat, G., Wang, X., Li, X., Kong, X., Wang, Y., Ning, Y., Zhang, H., 2016. The Asian monsoon over the past 640,000 years and ice age terminations. Nature 640, 640-646. https//doi.org/10.1038/nature18591.

Crawfurd, K.J., Alvarez-Fernandez, S., Kristina, D.A., Mojica, K.D.A., Riebesell, U., Brussaard, C.P.D., 2017. Alterations in microbial community composition with increasing $f \mathrm{CO}_{2}$ : a mesocosm study in the eastern Baltic Sea Biogeosciences, 14, 3831-3849. https//doi.org/10.5194/bg-14-3831-2017.

Crutzen, P.J., Stoermer, E.F., 2000. The Anthropocene. Global Change Newsletter 41, 17-18.

Dean, J.R, Leng, M.J., Mackay, A.W., 2014. Is there an isotopic signature of the Anthropocene? The Anthropocene Review 1, 276-287. https//doi.org/10.1177/2053019614541631

David, P., Thébault, E., Anneville, O., Duyck, P.F., Chapuis, E., Loeuille, N., 2016.Impacts of invasive species on food webs: a review of empirical data. Advances in Ecological Research 56, 2-50. https//doi.org/10.1016/bs.aecr.2016.10.001.

Doherty, T.S., Glen, A.S., Nimmo, D.G., Ritchie, E.G., Chris, R., Dickman, C.R., 2016. Invasive predators and global biodiversity loss. Proceedings of National Academy of Science. 113 (40), 11261-11265. https//doi.org/10.1073/ pnas. 1602480113

Fuller, D.Q., van Etten, J., Manning, K., Castillo, C., KingwellBanham, E. 2011. The contribution of rice agriculture and livestock pastoralism to prehistoric methane levels: an archeological assessment. Holocene 21, 743-759. doi:10.1177/0959683611398052.

Gallardo, B., Clavero, M., Sánchez, M. I., Vilà, M., 2015. Global ecological impacts of invasive species in aquatic ecosystems. Global Change Biology 22 (1), 151-163. https//doi.org/ 10.1111/gcb.13004.

Galloway, J.M., Aber, J.D., Erisman, J.W., Seitzinger, S.P., Howarth, R.W., Cowling, E.B., Cosby, B.J., 2003. The nitrogen cascade. Bioscience 53, 341-356. https//doi.org/ 10.1641/0006-3568 053[0341:tnc]2.0.co,2.

García-Robledo, G., Kuprewicz, E.K., Staines, C.L., Erwin, T.L., Kress, W.J., 2015. Limited tolerance by insects to high temperatures across tropical elevational gradients and the implications of global warming for extinction. Proceedings of National Academy of Science113 (3), 680-685. https//doi.org/10.1073/pnas.1507681113.

Gibbard, P.L., Head, M.J., Walker, M.J.C., 2010. Subcommissionon Quaternary Stratigraphy.Formal ratification of the Quaternary System/ Period and the Pleistocene 
Series/Epoch with a base at $2.58 \mathrm{Ma}$. Journal of Quaternary Science25, 96-102. https//doi.org/10.1002/jqs.1338

Gavrilets, S., 2004. Fitness landscapes and the origin of species. Princeton University Press, 41 William Street, Princeton, New Jersey 08540. https//doi.org/10.1111/j.1442-9993.2005.01455.x.

Halverson, G.P., Hurtgen, M.T., Porter, S.M., Collins, A.S. 2009. Neoproterozoic-Cambrian Biogeochemical Evolution. In: Gaucher, C., Sial, A.N., Halverson, G.P., Frimmel, H.E. (Eds.): Neoproterozoic-Cambrian Tectonics, Global Change and Evolution: a focus on southwestern Gondwana. Developments in Precambrian Geology, 16, Elsevier, pp. 351-365.

IPCC, 2014. Climate Change 2014: Synthesis Report. Contribution of Working Groups I, II and III to the Fifth Assessment Report of the Intergovernmental Panel on Climate Change [Core Writing Team, R.K. Pachauri and L.A. Meyer (eds.)]. IPCC, Geneva, Switzerland, 151 p.

Ives, A.R., Carpenter, S.R., 2007. Stability and diversity of ecosystems. Science317, 58.doi:10.1126/science.1133258.

Lande, R., Shannon, S., 1996. The Role of Genetic Variation in Adaptation and Population Persistence in a Changing Environment. Evolution $50 \quad$ (1) 434-437. https//doi.org/10.1111/j.1558-5646.1996.tb04504.x.

Loulergue, L., Schilt, A., Spahni, R., Masson-Delmotte, V., Blunier, T., Lemieux, B., Barnola, J.-M., Raynaud, D., Stocker, T.F., Chappellaz, J., 2008. Orbital and millennial-scale features of atmospheric $\mathrm{CH}_{4}$ over the past 800,000 years. Nature 453, 383 386. https//doi.org/10.1038/Nature06950.

Lüthi, D., Le Floch, M., Bereiter, B., Blunier, T., Barnola, J.-M., Siegenthaler, U., Raynaud, D., Jouzel, J., Fischer, H., Kawamura, K., Stocker, T.F., 2008. High-resolution carbon dioxide concentration record $650,000-800,000$ years before present. Nature, 453, 379-382. https//doi.org/ 10.1038 / nature06949

MacFarling, M., Etheridge, D., Trudinger, C., Steele, P., Langenfelds, R., Ommen, T., Smith, A., Elkins, J., 2006. The Law Dome $\mathrm{CO}_{2}, \mathrm{CH}_{4}$ and $\mathrm{N}_{2} \mathrm{O}$ Ice Core Records Extended to 2000 years BP. Geophysical Research Letters 33, L14810. https//doi.org/10.1029/2006gl026152.

McNeill, J.R., 2000. Something new under the sun: an environmental history of the twentieth century world. London, UK: W.W. Norton. https//doi.org/10.2307/2700702.

Mollot, G., Pantel, J.H., Romanuk, T.N., 2017. The Effects of Invasive Species on the Decline in Species Richness. Advances in Ecological Research, 61-83. https//doi.org/ 10.1016/bs.aecr.2016.10.002.

Morellato, L.P.C., Haddad, C.F.B., 2000. Introduction: The Brazilian Atlantic Forest. Biotropica 32, 786-792.

Pimm, S.L., Jenkins, C.N., Abell, R., Brooks, T.M., Gittleman, J.L., Joppa, L.N., Raven, P.H., Roberts, C.M., Sexton, J.O., 2014. The biodiversity of species and their rates of extinction, distribution, and protection. Science 344, 1246752-1. https//doi.org/10.1126/science.1246752.

Rasmussen, S.O., Bigler, M., Blokley, S.P., Blunier, T., Buchardt, S.L., Clausen, H.B., Cvianovic, I., Dahl-Jensen, D., Johnsen, S.J., Fischer, H., Gkinis, V., Guuillevic, M., Hoek, W.Z., Lowe, J.J., Pedro, J.B., Popp, T., Seiestadt, I.K., Steffensen, J.P., Svenson, A.M., Vallelonga, P., Vinther, B.M., Walker, M.J.C., Wheatley, J.J., Wintrup, M. 2014. Stratigraphic framework for
REVIEW PAPER

abrupt climatic changes during the Last Glacial period based on three synchronized Greenland ice-core records: refining and extending the Intimate event stratigraphy. Quaternary Science Reviews, 106, 14-28. https//doi.org/ 10.1016/j.quascirev.2014.09.007.

Raymo, M.E., Ruddiman, W.F., Backman J., Clement, M., Martinson, D.G., 1989. Late Pliocene variation in northern hemisphere ice sheets and North Atlantic deep-water circulation. Paleoceanography 4, 413-446. https//doi.org/ 10.1029/pa004i004p00413.

Renberg, I., Brännvall, M., Bindler, R., Emteryd, O. 2002. Stable lead isotopes and lake sediments - A useful combination for the study of atmospheric lead pollution history. The Science of the Total Environment 292, 45-54.

Rosman, K.J.R., Chisholm W., Hong, S., Candelone, J-P., Boutron, C., 1997. Lead from Carthaginian and Roman Spanish mines isotopically identified in Greenland ice dated from 600 B.C. to 300 A.D. Environmental Science and Technology 31, 34133416.

Ruddiman, W.F., 2013. The Anthropocene. Annual Review of Earth and Planetary Sciences 41, 45-68. https//doi.org/ 10.1146/annurev-earth-050212-123944.

Ruddiman, W.F., 2008. Earth's climate: past and future. 2nd Edition. New York, W.H. Freeman, 465 p.

Ruddiman, W.F., Thompson, J.S., 2001. The case for human causes of increasedatmospheric $\mathrm{CH}_{4}$ over the last 5000 years. Quaternary Science Reviews 20, 1769-1777.

Seki, O., Foster, G.L., Schmidt, D.N., Mackensen, A., Kawamura, K., Pancost, R.D., 2010. Alkenone and boron-based Pliocene $\mathrm{pCO}_{2}$ records. Earth and Planetary Science Letters. v. 292, p. 201-211. https//doi.org/10.1016/j.epsl.2010.01.037

Shibata, H., Branquinho, C., McDowell, W.H., Mitchell, M.J., Monteith, D.T., Tang, J., Arvola, L., Cruz, C., Cusack, D.C., Halada, L., Kopáček, J., Máguas, C., Sajidu, S., Schubert, H., Tokuchi, N., Záhora, J., 2015. Consequence of altered nitrogen cycles in the coupled human and ecological system under changing climate: The need for long-term and site-based research. Ambio 44(3), 178-193. https//doi.org/ 10.1007/s13280-014-0545-4].

Sinha, D.K., Singh, A.K., Mallick, K., Singh, V.P., 2013. Holocene: definition and current stratigraphic status in the geological time scale. In: Holocene: Perspectives, Environmental Dynamics and Impact Events (Ed. B.S. Kotlia), Nova Science Publishers, USA.

Steffen, W., Grinevald, J., Crutzen, P., McNeill, J., 2011. The Anthropocene: Conceptual and historical perspectives. Philosophical Transactions of the Royal Society, 369, 842-867, https//doi.org/10.1098/rsta.2010.0327

Stocker, T.F., D. Qin, G.-K. Plattner, L.V. Alexander, S.K. Allen, N.L. Bindoff, F.-M. Bréon, J.A. Church, U. Cubasch, S. Emori, P. Forster, P. Friedlingstein, N. Gillett, J.M. Gregory, D.L. Hartmann, E. Jansen, B. Kirtman, R. Knutti, K. Krishna Kumar, P. Lemke, J. Marotzke, V. Masson-Delmotte, G.A. Meehl, I.I. Mokhov, S. Piao, V. Ramaswamy, D. Randall, M. Rhein, M. Rojas, C. Sabine, D. Shindell, L.D. Talley, D.G. Vaughan and S.-P. Xie, 2013: Technical Summary. In: Climate Change 2013: The Physical Science Basis. Contribution of Working Group I to the Fifth Assessment Report of the Intergovernmental Panel on Climate Change [Stocker, T.F., D. Qin, G. K. Plattner, M. Tignor, S.K. Allen, J. Boschung, A. 
Nauels, Y. Xia, V. Bex and P.M. Midgley (eds.)]. Cambridge University Press, Cambridge, United Kingdom and New York, NY, USA, pp. 31-116. https://doi.org/ 10.1017/CBO9781107415324.005

Volanthen, K.A., Müller, R., Lundsgaard-Hansen, B., Roy, D., Di Piazza, S., Largiader, C.R. and Seehausen, O., 2012. Eutrophication causes speciation reversal in whitefish adaptive radiations. Nature 482, 357-362. https//doi.org/ $10.1038 /$ nature10824.

Wang, X., Shi, X., Tang, D., and Zhang, W., 2013. Nitrogen Isotope Evidence for Redox Variations at the EdiacaranCambrian Transition in South China. The Journal of Geology, 121(5), 489-502. https//doi.org/10.1086/671396

Waters, C.N., Zalasiewicz, J., Summerhayes, C., Barnosky, A.D., Poirier, C., Gałuszka, A., Cearreta, A., Edgeworth, M., Ellis, E.C., Ellis, M., Jeandel, C., Leinfelder, R., McNeill, J.R., Richter, D.B., Steffen, W., Syvitski, J., Vidas, D., Wagreich, M., Williams, M., Zhisheng, A., Grinevald, J., Odada, E., Oreskes, N., Wolfe, A.P., 2016.The Anthropocene is functionally and stratigraphically distinct from the Holocene. Science 351, aad2622-1. https//doi.org/10.1126/science.aad2622

Waters, C.N., Syvitski, J.P.M., Galuska, A., Hancock, G.J., Zalasiewicz, J., Cearreta, A., Grinevald, J., Jeandel, C., Mcneill, J.R., Summerhayes, C., Barnosky, A., 2015. Can nuclear weapons fallout mark the beginning of the Anthropocene Epoch?. Bulletin of the Atomic Scientists, 71, 46-57. https//doi.org/10.1177/0096340215581357
REVIEW PAPER

Wright, S., 1932. The roles of mutation, inbreeding, crossbreeding, and selection in evolution. Proceeding of the Sixth International Congress of Genetics, 1, p. 356-366.

Wu, M.-L., Wang, Y.-S., Wang, Y.-T., Yin, J.-P., Dong, J.-D., Jiang, Z.-Y., and Sun, F.-L., 2017. Scenarios of nutrient alterations and responses of phytoplankton in a changing Daya Bay, South China Sea. Journal of Marine Systems, 165, 1-12. https//doi.org/10.1016/j.jmarsys.2016.09.004.

Zalasiewicz, J., Waters, C.N., Sul, J.A.I., Corcoran, P.L., Barnosky, A.D., Cearreta, A., Edgeworthg, M., Gałuszkah, A., Jeandeli, C. Leinfelderj, R., McNeillk, J.R., Steffenl, W., Summerhayesm, C., Wagreich, M., Williams, M. Wolfe, A.P., Yonan, Y., 2016. The geological cycle of plastics and their use as a stratigraphic indicator of the Anthropocene. Antropocene, 13, p. 4-17. https//doi.org/10.1016/j.ancene.2016.01.002

Zhang, F., Algeo, T. J., Cui, Y., Shen, J., Song, H., Sano, H., Howe, H.D. and Anbar, A. D. 2018. Global-ocean redox variations across the Smithian-Spathian boundary linked to concurrent climatic and biotic changes. Earth-Science Reviews. https//doi.org/10.1016/j.earscirev.2018.10.012

Ziegler, M., Roik, A., Porter, A., Zubier, K., Mudarris, M. S., Ormond, R., andVoolstra, C. R. (2016). Coral microbial community dynamics in response to anthropogenic impacts near a major city in the central Red Sea. Marine Pollution Bulletin, 105(2), 629-640. https//doi.org/ 10.1016/j.marpolbul.2015.12.045. 